\title{
The baby bump. Pregnancy's new social visibility
}

Nella pancia delle donne. La nuova visibilità sociale della gravidanza

\section{Angela Biscaldi}

\section{OpenEdition}

\section{Journals}

\section{Electronic version}

URL: http://journals.openedition.org/aam/3447

DOI: $10.4000 /$ aam.3447

ISSN: 2038-3215

\section{Publisher}

Dipartimento Culture e Società - Università di Palermo

\section{Electronic reference}

Angela Biscaldi, "The baby bump. Pregnancy's new social visibility", Archivio antropologico mediterraneo [Online], Anno XXIII, n. 22 (2) | 2020, Online since 31 December 2020, connection on 28 January 2021. URL: http://journals.openedition.org/aam/3447 ; DOl: https://doi.org/10.4000/aam.3447

This text was automatically generated on 28 January 2021.

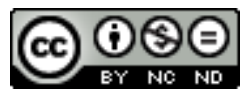

Archivio antropologico mediterraneo è distribuita con Licenza Creative Commons Attribuzione - Non commerciale - Non opere derivate 4.0 Internazionale. 


\section{The baby bump. Pregnancy's new social visibility}

Nella pancia delle donne. La nuova visibilità sociale della gravidanza

\section{Angela Biscaldi}

\section{Introduction}

1 In recent years, considerable effort has gone into investigating how new reproductive technologies and diagnostic tools have influenced the perception and experience of pregnancy and the decision-making processes it involves (Browner, Press 1996; Rapp 1999; Maher 2002; Tylor 2000; Harris et al. 2004; Thompson 2005; Faralli, Cortesi 2005; Inhorn, Birenbaum-Carmeli 2008) together with the impact these changes may have on the mother's (as well as the father's) future relationship with the expected baby. Less attention has been devoted to the change in pregnancy's representation in the public space, as fueled by the increasing use of new media (Biscaldi, Matera 2019).

2 When I was a little girl in the Seventies, my grandmother kept a stash (hidden well away from the children's eyes) of a gossip magazine called Stop, the sort of thing associated nowadays with checkout counter titillation, its cover blazoned with halfdressed starlets, its articles breathless accounts of illicit lovers and two-timing. Back in the day, such was the stuff of "scandal": the breakdown of an order, of marriage and family values, of what were then the proprieties.

3 Today, the front pages of these magazines still feature starlets and showgirls, but it is no longer (or not just) their lovers or their cleavages that are considered newsworthy. Oddly enough, what now captures the public's attention are rumors, news or images of their pregnancy or motherhood.

4 Front pages, TV shows and websites are full of celebs who proudly announce that they are pregnant, or would like to be, or have just become mothers - sometimes at an age when fifty years ago they would have been grannies. The baby bump is displayed, exhibited, decorated, tattooed, served up to the press and the public - an audience of 
the few or the many - like a trophy. It is the child, now, who is the object of desire and the subject of "scandal"; the child, now, who makes news. The child - not lovers and cleavages - is what the avid readers, the ladies at the hairdressers', the men leafing through the pages, want to know about.

5 Pregnant bellies, kept well under wraps until a few short decades ago, are now triumphantly posted and shared on social media, garnering admiration and likes. Even mothers who are far from famous - office workers, salesclerks, teachers, C-suite types pose for the photographers and put together pregnancy scrapbooks and albums portraying them, alone or accompanied, in every moment of the pre-partum path. Not only are bellies immortalized photographically from virtually every angle, they are also painted or cast ${ }^{1}$. And the photos are showcased in local shop windows.

Pregnancy, no longer a period of expectation and suspension, of intimate and unspoken imaginings, a moment of fixed rules and prohibitions - something not only to be concealed, but also to be mentioned publically as little as possible - has now become a time to be shared, displayed and shown off, and also a moment "to be enjoyed" or lived through as another of the many consumer experiences.

7 This paper is an invitation to reflect on this new social visibility that pregnancy has gained, and the cultural meanings associated with it. What does this belly containing the child represent? Why has it suddenly become an object of social attention? Why does it attract, intrigue, make news? And why - let's admit it - does it arouse envy? How can this displayed belly cast light on the new meaning of motherhood and family relationships in contemporary society? Can it perhaps also tell us something about the relationship the mother will have with the child, once born? I will propose four different interpretations of this phenomenon, guided by the voices of the thirty interviewed women - midwives, photographers, journalists, new mothers - and by their reflexivity.

8 Listening to their stories, we can interpret the display of the pregnant belly as another step in the objectification of the female body that began with the widespread use of diagnostic equipment in the Nineties (Duden 1994; 2006). Alternatively, we can think of it as the ultimate expression of the sacralization of the child, a tribute to the child's "singularization", a display of his or her uniqueness and of the special relationship that binds us to the child even before birth (Gauchet 2010). Or again, we can see it as flipping the stigma of the pregnant women who, by imbuing the belly with new meaning, exhibits that which for centuries was hidden, hushed up and feared, in what is almost a provocation: a visible symbol of women's liberation from the fate of forced motherhood. Lastly, we can interpret it as a new lay ritual that accompanies the woman on her path, reassuring her. Where the social fabric is raveling and the faith no longer sustains, the market spills into the gap with a new language, new practices, new representations, new ways to create bonds and communities.

Well aware of the fact that the critical paradigm (Butler 1990, 1997; Lock, Kaufert 1998; Moore 2006; Alison 2014) has revealed forms of domestication of women and their bodies (through a controversial concept of freedom), the aim of this contribution is not to endorse a clear-cut position, but to explore the multi-faceted reasons of women about their body exposure during pregnancy. Without claiming to cover the full complexity of the phenomenon, we will take the voices of the interviewed women as our starting point, drawing insights from them that will help us frame a number of 
questions about the complex process of becoming a mother - and desiring to be a mother - in contemporary society.

\section{Research methodology}

10 The in-depth interviews were carried out in different areas of Italy, from September 2018 to June 2019, with thirty women involved in different ways in the analyzed process: women, pregnant women, midwives, journalists, belly painters. As for the midwives and mothers interviewed, I involved a network of relationship activated and then consolidated on the occasion of previous research, whose sociological variables and lifestyles were well known to me (Biscaldi 2009; Biscaldi 2013). I tried to choose different women as far as their age range, educational background, occupation, composition of the family unit were concerned. For the selection of photographers and belly painters, I relied not only on the indications of the women interviewed (who they turned to, who they heard from), and on online research but also on the advice of photographer friends.

11 Most of the interviews were carried out in person at the interviewee's home or in photo studios; in the few cases where this was not possible, they were carried out by telephone or via Skype. In many cases the mothers showed me and commented on their pregnancy book; the photographers and belly painters showed me the set and some sessions made.

12 My goal was not to start from a pre-judicial position on the practice but to try to include as many points of view as possible, from which women represent their choices. The male point of view was deliberately excluded from the analysis, even if at times it entered tangentially into the interview setting: sometimes the women's partners attended, in a more or less participatory way, the interview, expressing their opinion; often the partners participate in various ways in the creation of the book, accompanying the future mother or posing with her. I think it would be interesting explore it in future research.

\section{Hypervisualism}

Barbara Duden points out that the somatic experience of pregnancy today is worlds away from the somatic experience of women of past generations: there is an abyss between our great-grandmothers' knowing they were pregnant when they felt a life quickening within them, and the diagnosed pregnancy of the mother of the new millennium. Pregnant women today learn, during their recurrent checks at the gynecologist, to look at what is going on in their womb on a screen, and feel it as their own through numbers, graphs and the physician's explanations. Feeling the changes taking place in the body has been superseded by gazing by appointment at the monitor. In addition, the hopes tied to a child's arrival, the willingness to wait for the full meaning of what is going on now to be revealed in the future, the musings and imaginings about the child - all of which lead us to realize that a child is not only other-than-self, but is also other than what we desire - have given way to a production process that must be as safe and surprise-free as possible (Marinopoulos 2008). 
Trust in what our senses tell us becomes trust in medical examination, with objective and repeated measurements. One's own, unique experience of giving life becomes "a program under technical surveillance". Duden emphasizes that even women's experience of corporeality is now given to them by technology; women learn not to trust their senses, but to "be told" by others (the physician, the tests) how they are doing:

being pregnant means learning to see one's body as a "fetal environment", taking responsibility for a bundle of genetically determined risks, being dependent on a complex consulting system (Duden 2006: 112).

Once technology takes over, women learn to stop paying attention to what their bodies are telling them - so that they can then tell their doctor in turn - but contemplate the fetus on a screen, delegating their experience to the expert's knowhow and waiting for the doctor to tell them "how they are". Through the sonogram, moreover, the interior is revealed, the barrier between inside and out disappears. The fetus becomes public, visible to all, it takes on an independent life of its own, becoming "The Life". The woman is transformed into a client who needs assistance and advice. The emotional and subjective experience becomes a medical matter.

Pursuing this line of thought, we can regard today's public display of the gravid belly in magazines and social media as a continuation of this change in the representation of the pregnant Self, an offshoot of the hypervisualism that has radically altered the process of becoming a mother. In this interpretation, displaying the "external" belly after the sonogram has provided a public view of what is going on inside - could be the last act in the sequence that has made the woman's body a "public" place, thus depriving her of any feeling of intimacy and the exclusive relationship with her pregnancy. Just as the rise of instrumental diagnostics made the woman a passive subject of medical knowledge (and of the bioethical discourse on Life), the public display of the belly has made her the subject of a social discourse that sees children as "luxury goods", the new status symbol. Likewise, it has made her the subject of the appearance- and performance-centered discourse that values her only to the extent that she continues to meet accepted standards of beauty or social acceptance.

The pregnant body exhibited on social media is once again a public body, not because it shows everyone what is going on inside it (as does the sonogram), but because in this case it shows everyone its outside, or in other words, the process of the belly that grows, putting a private event on display, complying with esthetic canons and seeking social approval.

Among the interviewees, those who think it is wrong to display the pregnant belly and those who approve - like the elderly midwife and the young photographer quoted below - both emphasize the importance now assigned to "looking good" and "feeling attractive" during pregnancy, prioritizing the sense of sight and the need for social recognition:

No, they're generations that've gone soft ... they're afraid ... they all have labor analgesia ... we gave birth naturally, we had our pain and that was that, end of story; nobody does that anymore ... they're very ... and OK ... maybe it's just me that's a bit backward in these things, I'm old school; they want to be in shape, pretty, trendy, they want to look good even when they're expecting ... show that they're attractive anyway ... there's a lot of superficiality around ... I see a lot of them...they're afraid of everything and instead of concentrating on the things that 
matter they've got this idea into their heads of being pretty and attractive even when they're pregnant (midwife, 63 years old, Pavia).

I think there's that amazement and the discovery of seeing yourself with ... another eye that isn't the mirror ... anyway we women have this lousy relationship with the mirror, don't we? Almost all of us do. But if somebody takes your photo and brings out the best in you, then there's that amazement ... ah ... so I'm not as ugly as I see myself in the mirror in the morning with no makeup and my hair in a mess, and then they feel they want to show off, in the good sense of the word ... and so I'm living through a wonderful time of my life, I look great, really beautiful ... look at that ... and then, yes ... the display comes but it comes afterwards (photographer, 45 years old, Cremona).

But we can also suggest that displaying the belly might be a reaction to medical objectification, a reaction intended to redirect attention away from what is happening inside ("the Life") and back to what is going on outside (the experience of a body transforming); from what objectifying medical knowledge sees to what the pregnant woman wants to show of herself, wants to tell and remember of her Self. If women's reproductive power is systematically subordinated to the demands of social control (Forni et al. 2005) that determine the authorized ways for representing and handling it, women's display of the belly could be a novel attempt to sweep away this preordained order and propose another, with a new language.

Is displaying the pregnant body in the media and on social networks a further stage in the process of expropriating pregnancy or a reaction to it? Is it a new way of objectifying the woman's body, or does it liberate it from the bonds of medical language, in the name of a new language - less technical, aseptic, standardized and cold? Is it another silencing of women's feelings, or a new way of giving voice and visibility to what women feel?

Some of the midwives who were interviewed, especially those of the older generation, were unsparing in their criticism of this practice, seeing it as a new form of objectification and of kowtowing to the dominant commodifying models. By contrast, some of the women I interviewed spoke of having their belly photographed and posting the picture as gratifying, a moment of free expression of the Self.

This brings us to yet another question. Barbara Duden emphasizes that technical language has transformed woman's individual experience in the objective process of "giving life", and thus paved the way to recognizing the embryo's right to Life as separate from the mother's rights. Following through on this perspective, then, we can ask: where will displaying the belly lead? What symbolic effect will it have on the social representation of the woman and the baby-to-be? Will it perhaps contribute to that process of sacralizing the child and its uniqueness that Marcel Gauchet (2009) maintains is characteristic of how childhood is pictured today?

\section{Desire}

Contemporary society has privatized procreation: with the separation of sexuality and reproduction and the ever more effective control of conception, children are no longer seen as a gift of God or nature, accepted as part of a worldview tinged with the unpredictable and unpreventable, but are the expression of a specific life plan, the emanation of the parents' (or the single parent's) most intimate being. Truly, they are 
"children of desire". The children of desire are an unprecedented break with the history of the human race:

The fact is not only that they entail a parental investment of a kind and an intensity that have never before been seen, with all the consequences that this brings as regards educational needs and, more generally, how the social and family spheres mesh; the fact is that the desire-which desire?-that presides over their entry into the world intervenes in forming people's identity to a degree we have never had occasion to consider before (Gauchet 2009: 18).

This individualization of conception not only concerns the decision to have a child (when, how and in what way), but also affects the gaze turned to the new arrival, who becomes the projection of the parent's Self and profoundest hopes.

From this perspective, we can hazard that the belly represents, at one and the same time, a goal achieved (for one parent or the couple), a wish come true, and an identity the mother's - affirmed through the fulfillment of an individual aspiration - an unprecedented investment in the unborn child. Displaying the belly can be considered as the expression of that process of "singularization" (Boltanski 2007) that begins on the day of conception and has now taken on particular social relevance.

of old, it was the family, as the legitimate social locus of reproduction, that made the child - or rather, many children. Today, it is the child that founds the family (as a distinct social environment, a place of personal realization), and anyone who has a child or even perhaps only wants a child or claims the right to have one can be considered a family. The child is called upon to legitimate and normalize unions, as is clear from the increasing number of couples aspiring to parenthood who until a few years ago were excluded (same-sex couples, for instance). The displayed belly seems to celebrate the extraordinary nature of the event it heralds: founding the family and, with it, society.

We can thus interpret displaying the belly as part of the individualization of people's biographies (Beck, Beck-Gernsheim 2002), where the child is increasingly the expression of a private, unique desire, and where - once the causal and ungovernable aspect of conception is no longer a factor - the child called for by the "parental project" is already valued for its absolute, unique, unrepeatable individuality even before birth: while still in the belly, in fact (Boltanski 2013).

Thus seen, displaying the belly is a contribution to the child's "singularization", a manifestation of its uniqueness, of the fact that it is expected and desired, and of the mother's joy which is thus made public, demonstrated and shared. Many of the interviewees' comments, in fact, draw a connection between the uniqueness of this moment in their lives and the desire to have their belly photographed and post the picture:

I think because ... well ... it was a wonderful time for me ... so I think that if you don't make a record of this moment ... maybe it's even a time when a women, if she's never had her photo taken, for this moment in her life, which is absolutely the most wonderful, you want to have a record of it and you want to do it right ... yeah, well, I don't know ... as I see it, that could be the justification ... even a woman who doesn't have a lot of money ... you say, what the hell, it's the most wonderful time of my life ...

Women today are more used to staying with a child than with a husband, sure ... that's really the way it is for me, personally ... I'd never have thought it would be like that, because when I was young I always had a boyfriend ... I could do without a 
man ... my son is enough for me, I feel completely fulfilled ... completely, in everything" (single mother, 40, Florence).

I saw it as something really personal, the first, maybe, real photo with my daughter... in our sense ... me and her and nothing else ... something we had together ... I chose, maybe I chose the first thing for her because at the end it's not as if ... it was this ... (mother, 43 , Naples).

the greatest joy of my life, a unique moment, unrepeatable, that will never come back ... a moment to be remembered forever ... (mother, 47, Rome).

\section{Flipping the stigma}

30 as a way of flipping the stigma attached to the gestating woman who, by imbuing the belly with new meaning, exhibits that which for centuries was hidden, hushed up and feared (Goffman 2003). She does so provocatively, with conscious irony, turning what was once a necessary destiny - associated with dread, pain and danger - into a selfcongratulatory choice. Behind the display, then, lies the desire to transform a natural and social obligation, a period in which life itself was at risk, into a taut new symbol of empowerment and prestige.

As we know, meanings that have been slowly deposited over the course of history, crystallizing into habits, practices, representations, are always liable to manipulation and change by social actors and actresses. And so any given object, attitude or behavior can also take on new meanings. In our case here, a sign of stigma, of belonging to an illregarded category, is transformed into a proudly flaunted emblem. Pregnancy, from being a fate to be accepted and endured, is here freely chosen and joyfully exercised.

Starting with the feminism of the Seventies, as should be recalled, the grammar of women's emancipation has been defined by the body. The female body has sought to free itself of submission by making the body itself visible in its quest for freedom; an attempt to change the relationships between men and women by changing the relationship with one's own body.

In pregnancy, resemanticizing the belly, which in the public mind evokes a traditional, passively accepted womanhood, enables the belly to be made into a powerful ironic symbol of the rebellion against the reification and commodification of the female body. Several of the interviewees linked their display of the belly to a sense of liberation:

It's time we got rid of this ridiculous taboo ... with a lot of things ... not just pregnancy... the fact that you didn't get married, the fact that you don't have your baby baptized ... the fact that you, you've got tattoos ... enough!

Interviewer: - You see it as kind of a liberation for women?

- Yes, yes, entirely, in everything (mother, 44, Cremona).

Maybe we've got out a bit ... we've freed ourselves a bit ... we've got away from that close-mindedness there used to be ... but just babies that used to be all swaddled up ... and now at two or three months they already seem like big kids ... but why have them grow up right away, leave them in peace, let them do what they want ... before they swaddled them ... you'd see these babies, poor little lumps ... what could they do? Nothing! Women have changed that way too ... they're much more emancipated ... even too much in some respects (belly painter and mother, 35, Milan).

if you think about it, back then all the female, reproductive part was something to be hidden ... take when your first period was about to come, for example ... I've got what my mother, my grandmother, said, where nobody explained the period to 
girls; at certain point they found themselves bleeding and there was a lot of fear. Now the approach to sexuality has also changed, I mean in the sense that what happens to our body has changed radically, I mean pregnancy has become something normal, not private, far from it, look at how many pregnant women you see in bathing suits, belly and all; when I was expecting I would go to the pool and my mother would tell me, no, don't do that ... don't make an exhibit of yourself like that ... it's disgusting ... showing your belly... but the belly is a beautiful thing to show off ... I mean, I think ideas about manners have really changed ... (mother, 50, Perugia). pregnancy, noting that the debate - both in the church and among laypeople - has focused chiefly on the issues of abortion, artificial insemination, or childbirth. We can postulate that the void surrounding this period - a void of reflexivity, social support and attention, bioethical criticism - has been filled with new practices and rituals, new purveyors of reassurance, and by the entry of the market which has seized on the "vacant" period of expectation and flooded it with facile consumer experiences (Taylor 2000).

As Alain Badiou (2006) reminds us, the market's control is more constant, surer, and more massive than the patriarchal control over women ever was: little wonder, then, that when the social fabric is unable to counter mothers' new anxieties and meet their new demands for meaning, a hypertrophic market steps in and saturates the experience of pregnancy by selling products and services of all kinds, and repackaging the experience of carrying a child as part of the experience of consumption and use -

Archivio antropologico mediterraneo, Anno XXIII, n. 22 (2) | 2020 
an experience whose language is familiar, simple and, for that reason, reassuring. Belly painting, belly casting, the pregnancy memory books and destination baby showers are all new moments of socialization. Though they are by no means free, the woman herself seems free to express her own opinion and her own tastes, in circumstances that are generally enjoyable and make few demands on her.

By contrast, pregnancy, though a physiological event, is increasingly being treated as pathological: with continual checkups, tests, and appointments with specialists. In this process, the woman is steadily deprived of control over her experience, if not indeed subjected to a form of violence; rarely is she allowed a voice in the decisions concerning her. It is thus that displaying the belly is fueled and sustained by the market, becoming a consumer experience like any other, and at the same time emerges as a form of social ritual that can reassure, build bonds and attract attention to the Self.

Showing yourself is a way of seeking approval and has the same needs as the woman of 500 years ago, to be protected and taken care of ... the woman needs to be protected and taken care of during pregnancy; showing yourself in this way is to get approval, approval you don't get from the rest, you don't get it from an authority any more, not from a law any more ... not from a custom ... not from an employer ... not from what are supposed to be the institutions, they don't protect the woman any more ... (midwife, 40, Pavia).

Social media can protect you ... If you talk with these women, they feel alone ..." "But what do you feel?" "Sharing such a wonderful thing makes me feel good" Why do you have to share it with so many people? Because the ones close to you aren't enough ... because there's an enormous need to be looked after and protected ... women give birth and they go on WhatsApp, on the groups ... they create ... they share everything because they don't have the answers ... the female culture of taking care of each other doesn't exist anymore ... we've put it all in the hospices ... all the old folk wisdom ... we've shut it up in the hospices ... every woman has to work just as hard to take care of her child as the first woman, and what's more, she has all the outside stimuli ... and so the woman has to come out of the hospital and be just as thin as before, hide the most beautiful event in her life, certainly the biggest thing she's ever done ... the physical marks have got to go ... the breasts have got to go back the way they were, actually, the marks of pregnancy have always been an honor, up to 79, 80 years ago ... now you're afraid because before the woman was really worshipped and in the cultures where the woman is really worshiped as a mother there's no need to make a display of pregnancy (midwife, 50, Cremona).

A tremendous call for help ... a need to be approved of, a need to be seen because so many times the woman is invisible ... the fact that somebody else sees is like saying I exist! I'm here! Look at me, I exist ... I'm pregnant! I'm pregnant, look at me! I need to show I'm not the same as before ... I'm pregnant!!! Even those photos where you see the belly growing ... I'm doing that! it really almost seems that people forget they're having a baby ... a woman is rarely asked how she's doing ... Are the tests OK? (gestures)... yes, but me, how am I ... what's it doing to me ... what impact does this have on my life? (midwife, 45, Milan).

when I started, speaking for myself, social media became ... how shall I say, my heart's choice (laughs) ... in the sense that then I was looking for consolation anywhere I could receive words of help or comfort, and so ... social media more than with photos ... it got to be ... venting, with anything that came into my head ... posted everything ... it got to be like that for me (single mother, 40, Riccione).

As Han (2013) notes, we can regard pregnancy as a "literacy event", not just because women learn to read new texts (from books about pregnancy to sonograms), but also because they learn, through literacy practices, how they are supposed to experience 
this moment of their lives and how they are supposed to be good mothers. An important part of this learning process is "belly talk":

Talk to the belly makes the unseen, unknown, and uncertain "baby" in the belly real and present to the pregnant women, other adults, and the children who engage it through talk" (Han 2013, p. 69).

Photographing the belly and posting the picture have the same meaning; it is a language that socializes women to their role as mothers, teaching them that they should be proud of their belly and that their belly can bring them joy, visibility, popularity.

\section{Conclusions}

41 In the past, motherhood was "women's destiny", given the lack of birth control and the high risk of mortality for mother and infant. Today, biomedical progress and the rapid rate of sociocultural change have enabled the female imagination to contemplate new outlooks and approaches to parenting, shifting women's attention to the issue of free choice and personal responsibility. Now that motherhood has become a medical matter and fertility can be controlled medically, the ability to decide when and how to become a mother (motherhood as a project) has put women up against decisions and responsibilities that once were inconceivable. Or so, at least, today's collective imagination would seem to suggest: pregnancy has become a choice and a life project.

This ability to choose has complicated the sociocultural picture surrounding pregnancy: women now become pregnant into their fifties; their family arrangements have multiplied, and we now have single mothers, mothers in reconstituted families, migrant mothers and surrogate mothers; the range of options for prenatal testing and birthing methods has expanded, becoming a market like any other.

The women I listened to realize - some very consciously, others somewhat less so - that they are caught up in a true revolution in the value and social meaning assigned to pregnancy. In a certain sense, however, this revolution has left them feeling as powerless and as fragile as their grandmothers. The "rhetoric of choice", of "being oneself", of "liking oneself", underlie an individualistic lexicon that completely removes the themes of political and cultural conditioning from the public space, shifting attention to the private and individual responsibilities. What is striking is the correspondence between the narrative that women make of their pregnancy and the characteristics of the subject required by neoliberalism: at the center is the theme of satisfying life choices and the search to make one's existence understandable and meaningful through a story which emphasizes well-being and autonomy. In showing the baby bump, well-being and autonomy are not only experienced but also exhibited and socially expendable (Alison 2014; Gill 2007; Simone 2012).

Pregnancy seems to be at the center of a series of contradictions. On the one hand, the broader array of medical tests and checks now available should make pregnancy safer; on the other, growing social worries revolve around the child's health and how perfect it is expected to be, while the narcissistic investment in the child has increased exponentially. Though the market provides the pregnant woman with every comfort and the illusion that the birth is recognized as unique and personal, it is also true that medicalization and hospital control over the birth are still at very high levels, as is women's dissatisfaction with how this special moment in their lives is managed ${ }^{3}$. 
49

Though the opportunities for older or initially infertile women to become pregnant have increased, these pregnancies are often difficult and fraught with anxiety. For older first-time mothers, support from family members frequently drops to nearly nothing, and the women are caught between childcare and looking after elderly parents (Osservatorio Nazionale sulla salute della donna 2018).

Thus, then, displaying the belly in the public space seems - in our four proposed interpretations - to shine a light on the complexity of a historical moment in which the market's offerings, the power of medical science, social pressures and the cultural representation of what an attractive woman and a good mother ought to be, the neoliberal rhetoric of fulfilled life converge and clash. Undoubtedly, the elderly midwife and her younger counterpart, the photographer, the expectant mother and the professional belly painter all have different points of view and different interests in this display, but the story they told is the story of a society where having a child has become a significant social fact, special and singular.

Shorn of the rhetoric of the natural and the necessary, having a child has moved into the semantic field of the extraordinary, unique and unrepeatable. And it is for this reason that it must be documented moment by moment, shared, enjoyed and made the most of. Social networks provide a key space for amplifying and giving visibility to the entire process, as well as an arena for exchanging views and finding social support (Baker, Yang 2018; Cosetta, Caliandro 2013). They are spaces of agency where women can exert a certain amount of control, or rather, retake control over their pregnancy from the medical system (Davis-Floyd 1992; Davis-Floyd, Sargent 1997; Lazarus 1994; Browner 2000), where they can express emotions, describe symptoms, ask for advice, share anxieties and worries, and act on their responsibilities (Johnson 2014); here, they can bring a part of the story of pregnancy onto the public scene: the part neglected in today's institutional spaces. With photos, videos and narratives, women seek to "personalize" their experience in a system that thinks in terms of standards and protocols; in doing so, they give visibility to the work of pregnancy, becoming active, making and sharing decisions. Social networks are also a place where women can settle their questions about whether displaying the belly is "permissible".

Significantly, in the debate about the acceptability of showing the pregnant belly ("is it right or not?", "can you or can't you do it?) on a number of women's sites, one of the most frequent arguments for taking a more "discreet" approach to one's pregnancy centers on the fact that some women feel that publicizing pregnancy on social platforms shows a lack of respect for women who cannot have children. This would appear to signal the fact that the belly is regarded as a success for women, something that can arouse envy, and that motherhood is (still) seen as one of woman's highest forms of fulfilment ${ }^{4}$.

Indeed, part of the feminist literature (Bordo 2003; Hartman 2004; Brown 2005) sees this pullulation of beguiling bellies in the press as an expression of the pronatalist discourse that seeks to influence women's decision-making processes by stressing the importance of pregnancy in a woman's life, as a unique event that fills it with value and meaning:

Motherhood is the "enduring" defining behavior of the female gender role, so with the media functioning as a "pronatalist juggernaut" (Tietjens Meyers 2001: 759).

Some may argue that putting the belly in the fashion spotlight has nothing to do with choice and freedom and is actually one more conspiracy to control women. The glamorisation of pregnancy, the decorated belly, the ethereal beauty of mother 
and child, can be seen as an excellent growth programme in family planning and population policy....It may be going out on an interpretative limb to comment that one of the reasons that the belly is receiving so much attention is because it is the last "cry" of a world where, in the next few generations, pregnancy as we presently know it may cease to exist (Trakas 2009: 69).

Social media's insistence on the value and beauty of pregnancy (a perfect pregnancy) and A-listers' gushings about how gratified being mothers makes them feel (Gentile 2011) seem to propose an ideal of the woman based on the cult of motherhood and domesticity, overshadowing all other spheres of female fulfilment. In addition, the media attention directed towards women's reproductive potential seems able to calm, if not indeed anesthetize, and reassure in a period of economic crisis and social upheaval. Publically displayed, women's pregnant body would appear to represent - as other forms of representation have done in other periods of history - social organization's capacity and need to renew itself (Gentile 2011); it is a model, a warning and at the same time the staging of a process of social catharsis.

But displaying the belly during pregnancy is often only the beginning of a process: once born, the child will in turn be displayed and posted like a trophy on social networks and WhatsApp profiles and will frequently even be the protagonist of photo shoots in the same studies where the pregnant mother posed ${ }^{5}$. The displayed baby thus becomes the obvious and necessary continuation of the belly's visibility in the public space.

What I think is interesting to emphasize here is the link between the widespread belief that pregnancy is an informed choice (and as such is important and valuable), the idea that being "chosen" and "wanted" makes the child unique, the narcissist projection onto the child, and the exhibition of the child on social media (which can last until adolescence) as if he or she were part of the parents' online Self. We can thus conclude that whatever reason women may have for exhibiting their pregnancy - whether it is the need to regain control over one's body and personal narrative, the desire to show oneself, a question of aspiring to a different, less conventional way of experiencing maternity, or wanting to celebrate a period that is felt to be unique - the effects of this display on the bond with the baby who is about to be born tend to blur the differences between the mother's identity and the child's, in a preview of that over-investment in the child that makes it so complicated for today's parents and educators to show responsibility in the child's upbringing (Biscaldi 2009; 2013; 2018).

\section{BIBLIOGRAPHY}

Alison P., 2014 The politics of the body: gender in a neoliberal and conservative age, Polity Press, Cambridge.

Badiou A., 2006 «The Law on the Islamic Headscarf», in A. Badiou, C. Winter, S. Corcoran (eds.), Polemics, Verso, New York: 98-110 (original French version in Le Monde, February 22/23, 2004).

Baker B., Yang I., 2018 «Social media as social support in pregnancy and the postpartum», in Sexual \& Reproductive Healthcare, 17: 31-34. 
Beck U., Beck-Gernsheim E., 2002 Individualization. Institutionalized Individualism and its Social and Political Consequences, Sage, London.

Biscaldi A., 2009 Un figlio è sempre un figlio. L'immaginario degli adolescenti lombardi sulla generazione e sull'aborto, CISU, Cremona.

Biscaldi A., 2013 Etnografia della responsabilità educativa, Archetipo, Bologna.

Biscaldi A., 2018 «Chi ha il coraggio della critica culturale? Brevi note sull'agire responsabile», in Pedagogika XXI, 4: 9-13.

Biscaldi A., Matera V., 2019 Antropologia dei social media. Comunicare nel mondo globale, Carocci, Roma.

Boltanski L., 2013 The Foetal Condition: A Sociology of Engendering and Abortion, Polity Press, Cambridge (original edition 2004).

Botti C., 2007 Cattive madri. Una riflessione su bioetica e gravidanza, il Saggiatore, Milano.

Bordo S., 2003 «Are Mothers Persons? Reproductive Rights and the Politics of Subjectivity», in Unbearable weight: Feminism, Western culture, and the body, University of California Press, Berkeley: 72-98.

Bourdieu P., 2001 Masculine Domination, Polity Press, Cambridge (original edition 1998).

Brown W., 2005 Edgework: Critical Essays on Knowledge and Politics, Princeton University Press, Princeton.

Browner C.H, Press, N., 1996 «The Production of Authoritative Knowledge in American Prenatal Care», in Medical Anthropological Quarterly, 10, 2: 141-156.

Browner C.H., 2000 «Situating Women's Reproductive Activities», in American Anthropologist 102, (4): 773-788.

Butler J., 1990 Gender trouble: feminism and the subversion of identity, Routledge, New York.

Butler J., 1997 The psychic life of power: theories in subjection, Standford University Press, Standford.

Casalini B., 2001 «Rappresentazioni della femminilità, postmodernismo e sessismo», in Iride, XXIV, 62: 43-59.

Cosetta A., Caliandro A., 2013 «La maternità nelle narrazioni on-line» in Sociologia Italiana, 1: 79-101.

Davis-Floyd R., 1992 Birth as an American Rite of Passage, University of California Press, Berkeley.

Davis-Floyd R., Sargent C., 1997 Childbirth and Authoritative Knowledge: Cross-Cultural Perspectives, University of California Press, Berkeley.

Douglas M., 1970 Natural Symbols: Explorations in Cosmology, The Crescent Press, London.

Duden B., 1993 Disembodying Women: Perspectives on Pregnancy and the Unborn, Harvard University Press, Cambridge MA/London.

Duden B., 2006 I geni in testa e il feto in grembo. Sguardo storico sul corpo delle donne, Bollati Boringhieri, Torino.

Edmonds A., 2008 «Beauty and health: Anthropology perspectives», in MEDISCHE ANTROPOLOGIE, 20, 1: 151-162.

Faralli C., Cortesi C. (eds.), 2005 Nuove maternità. Riflessioni biotiche al femminile, Diabasis, Reggio Emilia. 
Forni S., Pennacini C., Pussetti C., 2006 Antropologia, genere, riproduzione, Carocci, Roma.

Fusaschi M., 2011 «"Designer Vagina”: immaginari dell'indecenza o ritorno all'età dell'innocenza?», in Genesis, X/1: 63-84.

Gauchet M., 2010 Il figlio del desiderio. Una rivoluzione antropologica, Vita e Pensiero, Milano.

Gentile K., 2011 «What about the Baby? The New Cult of Domesticity and Media Images of Pregnancy», in Studies in Gender and Sexuality, 12, 1: 38-58.

Gill R., 2007 «Postfeminist media culture: Elements of a sensibility», in European Journal of Cultural Studies, 10(2): 147-166.

Goffman E., 1963 Stigma. Notes on the Management of Spoiled Identity, Prentice-Hall, NewYork.

Han S., 2013 Pregnancy in Practice: Expectation and Experience in the Contemporary US, Berghahn Books, New York.

Harris G., Connor L., Bisits A., Higginbotham N., 2004 «"Seeing the Baby": Pleasures and Dilemmas of UltraSound Technologies for Primiparous Australian Women», in Medical Anthropology Quarterly, 18, 1: 23-47.

Hartman M.S, 2004 The Household and the Making of History; A Subversive View of the Western Past, Cambridge University Press, Cambridge.

Inhorn M.C., Birenbaum-Carmeli, D., 2008 «Assisted reproductive technologies and cultural change», in Annual Review of Anthropology, 37: 177-196.

Johnson S. A., 2014 «"Maternal Devices", Social Media and the Self-Management of Pregnancy, Mothering and Child Health», in Societies, 4: 330-350.

Lazarus E. S., 1994 «What Do Women Want?: Issues of Choice, Control, and Class in Pregnancy and Childbirth», in Medical Anthropology Quarterly 8(1): 25-46.

Lock M., Kaufert, P.A 1998 Pragmatic Women and Body Politics, Cambridge University Press, Cambridge.

Maher J., 2002 «Visibly Pregnant: Toward a Placental Body», in Feminist Review, 72: 95-107.

Marinopoulos S., 2008 Nell'intimo delle madri. Luci e ombre della maternità, Feltrinelli, Milano.

Moore H., 2006 The subject of anthropology: gender, symbolism and psychoanalysis, Polity Press, Cambridge.

Osservatorio Nazionale sulla salute della donna, 2018 La salute della donna. Caregiving, salute e qualità della vita. Libro bianco 2018, Franco Angeli, Milano.

Rapp R., 1999 Testing Women, Testing the Fetus: The Social Impact of Amniocentesis in America, Routledge, New York.

Simone A., 2012 (ed.), Sessismo democratico. L'uso strumentale delle donne nel neoliberismo, Mimesis, Milano.

Taylor J., 2000 «Of Sonograms and Baby Prams: Prenatal Diagnosis, Pregnancy and Consumption», in Feminist Studies, 26, 2: 391-418.

Thompson C., 2005 Making Parents: The Ontological Choreography of Reproductive Technologies, MIT Press, Cambridge, MA-London.

Thornham H., 2015 «Irreconcilability in the digital: gender, technological imaginings and maternal subjectivity», in Feminist Review, 110: 1-17. 
Tietjens Meyers, D., 2001 «The rush to motherhood. Pronatalist discourse and women's autonomy», in Signs, 26(3): 735-773.

Trakas D., 2009 «The belly beautiful: Unveiling the pregnant body», in MEDISCHE ANTROPOLOGIE, 21, 1: 53-72.

\section{NOTES}

1. In belly painting, a practice of US origin, professional paintresses decorate the expectant mother's belly, after which the woman poses for a photo shoot. Belly casting consists of making a plaster cast of the belly, usually at the eighth month of pregnancy. The mother then keeps the cast as a souvenir.

2. In this regard - the theme of the beauty of the body in pregnancy - it is worth noting Alexander Edmonds' reflection (2008) on the way in which aesthetics, the feeling of being healthy and the appearance of being healthy are linked and they shape each other.

From this point of view, the perception of the progress of one's pregnancy on the basis of a socially shared beauty model is part of those practices defined by the anthropologist as "aesthetic health", processes in which continuous improvement became desirable and possible and processes that rooted in some of the major change in the significance of health in the contemporary society. On the despotic power of the myth of beauty see also Casalini 2011.

3. https://ovoitalia.wordpress.com/indagine-doxa-ovoitalia/ accessed 1/05/2020.

4. "I didn't post a single photo of my pregnancy on social media ... because until this child was safely in my arms after delivery, I was never so comfortable to think that she would definitely arrive". Superstition? No, far from it. If anything, it's a question of sensitivity towards everybody who can't have children. The people who struggle for years and don't just suffer, but maybe even feel inadequate, because it seems as if everybody all around them does nothing but announce happy events. It's not just a matter of putting yourself in these people's shoes: Ellen understands that because she's been through it.

"The choice also came from a deep sensitivity to the pain that those happy announcement posts cause to women (and men) who are desperate to get pregnant and have a child but spend months and years and untold thousands of dollars 'trying'. Our pregnancy journey was too complicated to announce in a photo post or 140 character tweet, but I realize that means I was also part of the problem. In our hyper-curated social media lives, the stories of months of negative pregnancy tests, miscarriages, fetal health problems, or daily IVF injections seem to be missing from the scrolls of posts. But it doesn't mean they are not there".

(https://mamma.robadadonne.it/perche-non-ho-postato-una-singola-foto-della-mia-gravidanzasui-social/ accessed 1/05/2020).

And you, who work because you've always thought that personal fulfilment also means financial independence and a gratifying job, you who believe that the love you feel for your partner, for your parents, brothers and sisters and for your friends is absolutely "pure and absolute" and certainly not a junior league sort of love, you who've always thought of pets as part of your family because in a person's heart, a person's life there's room, thank god, for everybody; you who still dare post the snaps of your last trip or the link to an article that interested you and has nothing to do with the shocking lack of places in public day care centers, bullying kindergarten teachers and the pros and cons of vaccination, you're looked at with benevolent condescension, even with pity, because, basically, poor thing, you don't have kids.

(www.google.com/url?sa=t\&rct=j\&q=\&esrc=s\&source=web\&cd=39\&cad=rja\&

uact=8\&ved=2ahUKEwifooqr2fDkAhVCPVAKHcDGBi44HhAWMAh6BAgFEAE\&url=https\%3A\%2F\%2Fmedium.com\%2F\%40openspace.nam 
retorica-della-maternit\%25C3\%25A0-al-tempo-dei-social-network-66c8296fb717\&usg=

AOvVaw0UvFNq4vm87_Cj8dJPK9AO accessed 1/05/2020).

5. www.repubblica.it/robinson/2019/08/10/news/mamma_ho_perso_la_privacy_

sui_social_-233316314/ accessed 1/05/2020.

\section{ABSTRACTS}

This paper will offer several vantage points for interpreting a new social phenomenon: the flaunting of pregnancy in the public space, and in the media space in particular. In the last twenty years, the cultural meaning of pregnancy has been entirely upended: once a period of waiting, of suspension, almost mysterious and concealed, wrapped in prohibitions and fears, and surrounded by silence, pregnancy now seems to be something to be chronicled, savored and even exhibited by displaying the belly - painted or decorated - as if it were a trophy. Through thirty in-depth interviews with women in a range of occupations - midwives, photographers, belly painters and journalists - throughout Italy, we will attempt to explore the cultural meanings of this change.

L'obiettivo di questo contributo è fornire alcune chiavi interpretative per leggere un fenomeno sociale nuovo: l'esibizione della gravidanza nello spazio pubblico, in particolare quello mediatico. Negli ultimi venti anni si è infatti verificato un vero e proprio ribaltamento del significato culturale della gravidanza: da tempo dall'attesa, di sospensione, quasi misterioso e nascosto, avvolto in divieti e paure, circondato dal silenzio, oggi la gravidanza appare un momento da raccontare, fruire, anche esibire, attraverso l'esposizione della pancia - dipinta o decorata come un trofeo. A partire da trenta interviste in profondità realizzate a ostetriche, fotografe, pittrici di pance (belly painters), giornaliste in tutta Italia, cercheremo di indagare i significati culturali di questo cambiamento.

\section{INDEX}

Parole chiave: gravidanza, rappresentazioni culturali, nuovi media, responsabilità, spazio pubblico

Keywords: pregnancy, cultural representations, new media, responsibility, public space

\section{AUTHOR}

\section{ANGELA BISCALDI}

Dipartimento di Scienze Sociali e Politiche, Università degli Studi di Milano

angela.biscaldi@unimi.it 